\title{
Reproductive control of capybaras through sterilization in areas at risk of transmission of brazilian spotted fever
}

\section{Fernanda Battistella Passos Nunes ${ }^{1,3^{*}}$ Alexandre Zanetti Nunes ${ }^{1}$ (i) Mariana Passos Nunes $^{1}$ Marcelo Bahia Labruna ${ }^{2}$ (i) Cristiane Schilbach Pizzutto $^{3}$ (I)}

${ }^{1}$ A Z Nunes \& Cia Ltda, 13301-610, Itu, SP, Brasil. E-mail: passosnunes@uol.com.br. "Corresponding author.

${ }^{2}$ Departamento de Medicina Veterinária Preventiva e Saúde Animal, Faculdade de Medicina Veterinária e Zootecnia (FMVZ), Universidade de São Paulo (USP), São Paulo, SP, Brasil.

${ }^{3}$ Departamento de Reprodução Animal, Faculdade de Medicina Veterinária e Zootecnia (FMVZ ), Universidade de São Paulo (USP), São Paulo, SP, Brasil.

\begin{abstract}
Groups of capybaras (Hydrochoerus hydrochaeris) are currently frequent inhabitants of urban areas. The species participates in the transmission cycle of Brazilian spotted fever (BSF), a zoonosis that is caused by the bacteria R. rickettsii and transmitted by vector ticks. This has led to discussions on strategies to decrease the presence of this rodent through contraceptive methods and euthanasia, thus reducing their capacity to carry and transport ticks, which would be an important contribution to public health. Two condominiums and one business establishment in the interior of the state of São Paulo were used as case studies in the present investigation. All areas were classified by the Endemic Control Superintendence as risk areas for the transmission of BSF and presented the specie of ticks A. sculptum and A. dubitatum The objective of this study was to carry out sterilization procedures with animals that presented seropositive results for BSF. A total of 85 surgical procedures were conducted on immune capybaras, with authorization from DeFau/SMA-SP. For all procedures the animals were anesthetized with ketamine hydrochloride combined with xylazine and morphine. Two alpha males isolated themselves from the group after the vasectomy procedure, returning to their hierarchical position after 5 to 14 days. Population monitoring in the areas should be maintained indefinitely and conducting annual serological management until the natural death of these individuals. Tubal ligation, vasectomy and salpingo-oophorectomy were demonstrated to be simple and low-risk procedures in capybaras. These techniques assist in the population control of this species in enclosed areas with risk of BSF transmission, thus decreasing the need for euthanasia.
\end{abstract}

Key words: population control, preventive veterinary medicine, surgical techniques, zoonosis, spotted fever.

Controle reprodutivo de capivaras através de esterilização em áreas de risco de transmissão da febre maculosa brasileira

RESUMO: Grupos de capivaras (H. hydrochaeris) são atualmente habitantes frequentes de áreas urbanas. A espécie participa do ciclo de transmissão da febre maculosa brasileira (FMB), uma zoonose causada pela bactéria R. rickettsii e transmitida por carrapatos vetoriais. Isso levou a discussões sobre estratégias para diminuir a presença desse roedor por meio de métodos contraceptivos e eutanásia, reduzindo sua capacidade de carrear e transportar carrapatos, o que seria uma importante contribuição para a saúde pública. Dois condomínios e um estabelecimento comercial no interior de São Paulo foram utilizados como estudos de caso na presente investigação. Todas as áreas foram classificadas pela Superintendência de Controle Endêmico como áreas de risco para a transmissão da FMB e apresentaram a espécie do carrapato A. sculptum e A. dubitatum. O objetivo deste estudo foi realizar procedimentos de esterilização com animais que apresentaram resultados soropositivos para a FMB. Foram realizados 85 procedimentos cirúrgicos em capivaras imunes, com autorização do DeFau / SMA-SP. Para todos os procedimentos, os animais foram anestesiados com cloridrato de cetamina combinado com xilazina e morfina. Dois machos alfa se isolaram do grupo após o procedimento de vasectomia, retornando à sua posição hierárquica após 5 a 14 dias. O monitoramento populacional nas áreas deve ser mantido indefinidamente e conduzindo-se o manejo sorológico anual até a morte natural desses indivíduos. Foi possível demonstrar que a ligação tubária, vasectomia e salpingo-ooforectomia são procedimentos de baixo risco em capivaras. Essas técnicas auxiliam no controle populacional desta espécie em áreas fechadas e com risco de transmissão de FMB, diminuindo a necessidade de eutanásia.

Palavras-chave: controle populacional, medicina veterinária preventiva, técnicas cirúrgicas, zoonoses, febre maculosa.

\section{INTRODUCTION}

Groups of capybaras (Hydrochoerus hydrochaeris LINNAEUS, 1766) are currently very frequent inhabitants of urban areas. They are usually found near bodies of water and grassy areas (BOVO et al., 2016). The species participates in the transmission cycle of important zoonoses, such as the Brazilian spotted fever (BSF) (LABRUNA, 2013). This has raised questions about the risk of disease 
transmission when there are capybaras present in enclosed residential areas (PASSOS NUNES et al. 2019). The Amblyomma sculptum ticks acts as a vector for the transmission of BSF in the interior of the state of São Paulo, where horses and capybaras are primary hosts in endemic areas. Human beings are accidentally parasitized by all active stages of this tick (SOUZA et al., 2009). Rickettsia rickettsii, transmitted by the Amblyomma sculptum ticks, is the bacterial agent that causes BSF in the interior of São Paulo (PASSOS NUNES et al. 2019).

When a tick becomes infected by $R$. rickettsii while it feeds on capybara blood during the bacteremia phase, the following stage of this tick can become a transmitter for the disease (POLO et al., 2017). A seronegative capybara to rickettsiosis is considered susceptible when parasitized by a tick carrying $R$. rickettsii. This bacterium causes primary infection that is responsible for a bacteremia (rickettsemia) lasting around 14 days, making the animal seropositive or immune thereafter, for at least several years (SOUZA et al., 2009; RAMÍREZHERNÁNDEZ et al., 2020). In this case, seropositive capybaras will not develop further bacteremia, even if they are successively exposed to $R$. rickettsii-infected ticks (RAMÍREZ-HERNÁNDEZ et al., 2020).

Although, the capybara does not directly transmit the bacterium that causes BSF, it does have an important role in public health, since it amplifies the agent among ticks populations (LABRUNA, 2013).

Strategies to decrease capybara populations through contraceptive methods reduce their capacity to carry and transport ticks, and mostly important, reduce the number of newborns that could act as amplifying hosts through their primary infection by $R$. rickettsii (POLO et al., 2017; ROSENFIELD et al., 2019b; ROSENFIELD et al., 2019c). Hence, any method that decreases capybara reproduction in a BSF-endemic area can be an effective alternative to control the disease.

The aim of the present study was to carry out sterilization procedures in capybaras that presented seropositive results with the identification of anti- $R$. rickettsii antibodies, applying an innovative management practice and reproductive control for free-living capybaras.

\section{MATERIALS AND METHODS}

\section{Study location}

In2017, two closed residential condominiums and one business establishment in the municipalities of Cajamar $\left(23^{\circ} 17^{\prime} 8.02^{\prime}\right.$ 'S 46 $\left.52^{\prime} 11.67^{\prime \prime} \mathrm{W}\right)$, Porto

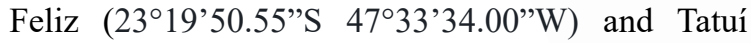
(2317'52.00'S $47^{\circ} 17^{\prime} 54.00^{\prime}$ 'W), in the countryside of the state of São Paulo, were classified by the "Superintendência de Controle de Endemias" (Sucen) as risk areas for the transmission of BSF. Two species of ticks, Amblyomma sculptum and Amblyomma dubitatum, were found in these areas.

The studied areas have various environments that are favorable for the establishment, maintenance and populational increase of capybaras, characterized by several lakes, grassy areas that are irrigated during the drought season, lowland vegetation and riparian forest fragments.

\section{Experimental design}

To carry out the sterilization procedures, first a survey was conducted regarding the capybara population, the number of groups in each region studied and the number of alpha males and dominant females in each of these groups of animals (Table 1). The following criteria were used to determine the alpha males: visible testicles, prominent nasal gland, territorial marking behavior using the nasal and anal glands, and leadership and group protection behaviors. In turn, dominating females were determined based on specific behavioral patterns, such as the oldest animals in the groups, the most aggressive during containment with the intention of protecting pups, territorial reactions towards other females when confined with vulvar secretion similar to the anal secretion of males, and also some females that presented remnants of androgen-dependent gland above the snout. Most dominant females are those that are either gestational or nursing and have greater body weight. They tend to accompany the alpha male and rear their pups in a communal system.

The management plan described in this study was established and authorized by DeFau/ SMA-SP (Department of Fauna/Secretariat for the Environment of the state of São Paulo) under the following registration numbers: Tatuí - No. 0000033882/19; Cajamar - No. 0000078525/17; Porto Feliz - No. 0000080229/17.

\section{Safety rules}

To handle the animals, the team was equipped with personal protective equipment. This included white rubber boots, white overalls (Tyvek ${ }^{\circledR}$ ) worn over one's clothes with long pants and long sleeves, socks worn over the hem of the pants, procedure gloves, wide and transparent doublesided adhesive tapes (Durex ${ }^{\circledR}$ ) between the boots and 
overalls, and insect repellent (Exposis $\left.{ }^{\circledR}\right)$. This was necessary to decrease the risk of ticks parasitism.

\section{Capture and collection of material}

Animals were lured with sugarcane and captured using metal chutes measuring approximately $24 \mathrm{~m}^{2}$, with a safety corridor of $6 \mathrm{~m}^{2}$ and two guillotine doors to facilitate handling (Figure 1A).

Once a group of up to 10 capybaras was captured, the animals were directed to the safety corridor area of the capture chute. They were then contained using anesthetic darts with a combination of ketamine hydrochloride $(10 \mathrm{mg} / \mathrm{Kg} / \mathrm{LW})$ and midazolam (0.5 to $1.0 \mathrm{mg} / \mathrm{Kg} / \mathrm{LW}$ ) (Figure 1B).

Once sedated, the animals were identified with numbered ear tags $\left(\right.$ Zootech $\left.^{\circledR}\right)$, microchipped $\left(\right.$ Animaltag $^{\circledR}$ ) and marked with a fur bleach on their backs to facilitate the visual monitoring of individuals that had gone through handling for a short period.

Two milliliters of blood were drawn from the femoral vein using $3-\mathrm{mL}$ syringes with $25 \times 7-\mathrm{mm}$ needles. The samples were later stored in sterile tubes with a separating gel. They were sent to the Laboratory of Parasitic Diseases of the Department of Preventive Veterinary Medicine and Animal Sciences of the University of São Paulo (VPS/FMVZ-USP), where the sera were separated by centrifugation, and then tested for the presence of anti- $R$. rickettsii antibodies by the immunofluorescence assay, as previously described (SOUZA et al., 2009). A capybara was considered seropositive if its serum reacted to $R$. rickettsii at the serum dilutions of both 64 and 128. Sera with no reaction at the 64 and 128 dilutions were considered seronegative. Sera with weak reactions, namely, sera reacting only at the 64 dilution and negative at the 128 dilution, were considered as seronegative.

The capybaras were kept either in individual boxes or in waiting pens until the serology results came in, which took around 24 hours since the collection of blood samples. Seropositive animals, considered immune, underwent surgical procedures of tubal ligations (non-gestational females) and vasectomy (males). Dominant gestational females underwent salpingo-oophorectomies. In these cases, a thiopental sodium anesthetic was applied at a dose of $1 \mathrm{mg} / \mathrm{Kg} / \mathrm{LW}$ in each fetus when removing the uterus, so to avoid fetal suffering.

Seronegative animals were euthanized under the terms of the aforementioned authorizations as a strategy to control the proliferation of the bacteria that causes BSF, a practice that is guaranteed by Joint Resolution SMA/SES No. 1, of July 2016.

\section{Surgical procedures \\ Vasectomy/deferentectomy}

Deferentectomy was conducted on immune males that were duly anesthetized with ketamine hydrochloride $(10 \mathrm{mg} / \mathrm{Kg} / \mathrm{LW})$, xylazine $(0.5$ to 1.0 $\mathrm{mg} / \mathrm{Kg} / \mathrm{LW})$ and morphine $(10 \mathrm{mg} / \mathrm{Kg} / \mathrm{LW})$. Animals were placed in supine position and procedures began with trichotomy and antisepsis of the inguinal region. A small incision was made to the lateral regions of the pubic symphysis, opening the subcutaneous region so to reach the spermatic cord and its ducts. After locating the structures, the deferent ducts were separated from the spermatic fascia, vein and arteries present in the spermatic cord, thus clamping both portions of the duct cranially and caudally. A space of
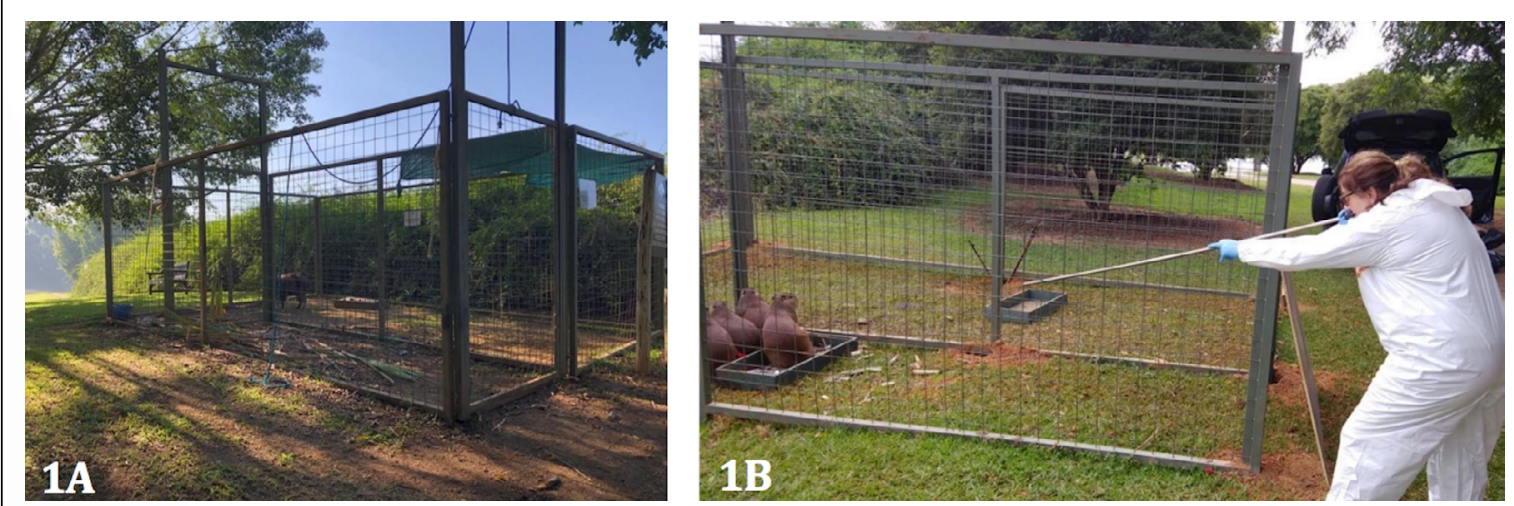

Figure 1 - (A) Animals captured in metal chutes; (B) Anesthetic darts used to contain animals.

Ciência Rural, v.50, n.9, 2020. 
$1 \mathrm{~cm}$ was left between the clamps, which is where the excision took place after conducting the procedure on these extremities (Figure 2A).

A 3.0 nylon cord was used in the ligature of the right and left vas deferens. After repositioning these structures in their original location, skin was sutured with a 3.0 nylon cord and surgical glue (Figure 2B).

\section{Tubal ligation}

Tubal ligation was conducted on immune females that were duly anesthetized with ketamine hydrochloride $(10 \mathrm{mg} / \mathrm{Kg} / \mathrm{LW})$, xylazine $(0.5$ to $1.0 \mathrm{mg} / \mathrm{Kg} / \mathrm{LW})$ and morphine $(10 \mathrm{mg} / \mathrm{Kg} / \mathrm{LW})$. Females were also placed in a supine position and procedures began with trichotomy, antisepsis, and a rectus abdominis midline incision of approximately $3 \mathrm{~cm}$ to access the cavity and divide the layers of the rectus abdominis muscle. Access is initially through the urinary bladder using the cystocentesis method, emptying the organ to facilitate identification of the uterus and uterine horns (Figure 2C), which are exposed to begin the procedure. The ligature of the tubal isthmus was carried out by clamping this structure on both sides, right and left, maintaining a small region (approximately $1 \mathrm{~cm}$ ) of the uterine tube between two clamps, which was then removed.

The cranial and caudal portions of the uterine tubes were then ligated with a 3.0 nylon cord on the right and left sides. The same ligation procedure was conducted in the contralateral tube.

After verifying the absence of hemorrhages, the organs were repositioned in the cavity for suturing with a 3.0 nylon cord. Muscle, subcutaneous and skin layers were sutured with separate simple stiches and surgical glue was used over the suture stiches (Figure 2D).

\section{Salpingo-oophorectomy}

Salpingo-oophorectomy was conducted in three immune adult females that were diagnosed

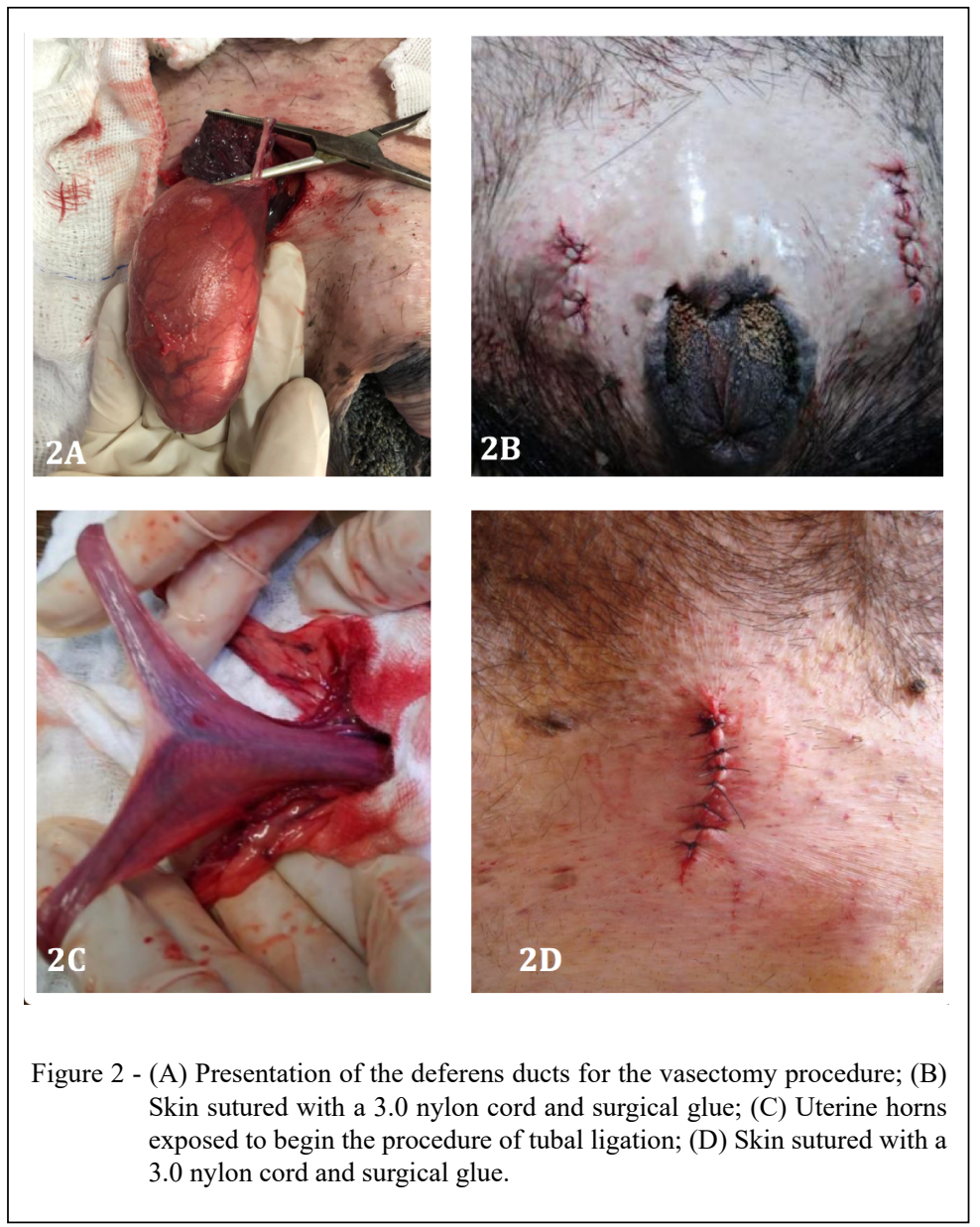

Ciência Rural, v.50, n.9, 2020. 
as gestational through a laboratory ultrasound examination at the time of the surgical procedure.

The animals were duly anesthetized with ketamine hydrochloride $(10 \mathrm{mg} / \mathrm{Kg} / \mathrm{LW})$, xylazine $(0.5$ to $1.0 \mathrm{mg} / \mathrm{Kg} / \mathrm{LW})$ and morphine $(10 \mathrm{mg} / \mathrm{Kg} /$ LW) and placed in supine position. As with the other procedures, the capybaras underwent trichotomy and antisepsis. A pre-retro-umbilical incision measuring approximately $3 \mathrm{~cm}$ was made just below the umbilical scar. Subcutaneous layers were then separated until the ventral midline became visible. A scalpel was used for the incision, while bluntblunt straight scissors were used to further separate the layers to both sides, cranially and caudally. After entering the abdominal cavity, the bladder was emptied through cystocentesis and the uterine horns were exposed either by hand or using a Snook castration hook. By pulling one of the uterine horns, the ovary is exposed. A hemostat was used to begin the anterior ligature of the ovary, with the intention of keeping it within the animal. The three clamps technique was applied, in which one clamp is inserted nearest to the ovary while another is at a distance of 2 $\mathrm{cm}$ from the first, and finally the third clamp is located $2 \mathrm{~cm}$ away from the second. Sutures were made using either absorbable 3.0 catgut or 3.0 nylon and clamps were removed after the incision and removal of the uterine horn. Clamps were then removed as a ligation was made using sutures. The same procedures are conducted for the contralateral uterine horn. After removal, the broad and round ligaments of the uterus were inspected and, if blood vessels were evident, they were ligated before sectioned. Using the same technique as with the uterine horns, three clamps were applied to the uterus body near the uterine cervix, sectioning between the proximal and medium clamps and sectioning the spot where the caudal clamp is located, ligating uterine arteries individually and caudally. After the last clamp was removed, the uterine stub was ligated with a continuous suture pattern. Finally, the abdominal wall was joined back together, reducing subcutaneous space and suturing the skin with a 3.0 nylon cord using simple separate stiches (BARROS et al., 2009).

\section{Postoperative period}

After the surgeries, all animals received intramuscular broad-spectrum and long-acting Agrovet $5,000,000$ antibiotics (procaine benzylpenicillin 3,750,000 IU; benzylpenicillin potassium 1,250,000 IU; streptomycin base (sulphate) $2.0 \mathrm{~g}$ ) at a dose of $1.0 \mathrm{~mL}$ for every $10 \mathrm{Kg} / \mathrm{LW}$; meloxicam $2 \%$ (dose: $0.6 \mathrm{mg}$ / $\mathrm{Kg} / \mathrm{LW}$ ) and Ivermectin (dose: $1 \mathrm{~mL} / 50 \mathrm{Kg} / \mathrm{LW}$ ).

Animals were only discharged once they were fully recovered from the effects of anesthesia. All individuals were released into the location from where they were captured after these reproductive management procedures.

\section{Behavior}

All animals were followed-up for 30 days after surgical procedures to assess their clinical condition and maintenance within their respective groups.

\section{RESULTS}

The dynamics of reproductive management in this study involved 11 groups of capybaras with sizes varying from two to 55 animals per group (Table 1). This variation of animals per group

Table 1 - Total number of capybaras per group from each municipality and number of dominant males in each group. São Paulo, 2019.

\begin{tabular}{lccc}
\hline Location & Group & Number of alpha males & Number of animals in group \\
\hline Tatuí & 1 & 2 & 21 \\
Tatuí & 2 & 1 & 11 \\
\hline Tatuí & 3 & 1 & 18 \\
Tatuí & 4 & 2 & 7 \\
\hline Porto Feliz & 1 & 1 & 27 \\
\hline Porto Feliz & 2 & 1 & 7 \\
\hline Porto Feliz & 3 & 1 & 8 \\
\hline Porto Feliz & 4 & 1 & 4 \\
\hline Porto Feliz & 5 & 1 & 14 \\
\hline Porto Feliz & 6 & 2 & 2 \\
\hline Cajamar & 7 & & 55 \\
\hline
\end{tabular}

Ciência Rural, v.50, n.9, 2020. 
was also confirmed through populational surveys conducted according to a pre-defined methodology of the Brazilian Institute of Environment and Renewable Natural Resources (IBAMA), which was named the Populational Diagnosis of the Capybara (IBAMA, 2006) (PASSOS NUNES et al. 2019). All capybaras submitted to surgery were seropositive to $R$. rickettsii (titers $\geq 128$ ).

Among the 11 studied groups, results showed that regardless of the size of the group, one or two males assumed a leadership/alpha position. This was confirmed by the presence of visible testicles, prominent nasal gland, territorial marking behavior using nasal and anal glands, and leadership and group protection behaviors.

A total of 85 surgical procedures were carried out in the present study. These comprised 48 tubal ligations, 34 vasectomies and 3 salpingooophorectomies in capybaras with ages starting at 2 months. The capybaras were followed up during the postoperative period for 30 days. With the exception of two alpha males, none of the animals demonstrated any type of behavior or clinical condition that indicated surgical complications that either required intervention or that represented an eminent threat to them. In the case, two dominant males (alpha) out of the 15 vasectomized individuals remained distant from their group for 5 to 14 days after returning from the surgical procedure (Figure 3). They returned to their position within the group after fighting satellite males that took advantage of their absence to dominate the groups.

\section{DISCUSSION}

With a focus on issues involved in One Health, this was the first study to the best of our knowledge to describe sterilization procedures on capybaras that were seropositive to anti- $R$. rickettsii antibodies, aiming for population control and proposing a control alternative for BSF. Our procedure to sterilize seropositive animals relied on the proposal that once seropositive, capybaras will not develop rickettsemia anymore, as recently demonstrated under experimental conditions (RAMÍREZ-HERNÁNDEZ et al., 2020). Conversely, seronegative capybaras (the ones prone to be primarily infected and to develop ricketsemia to generate infected ticks) were culled from the capybara population, with the aim to reduce the number of $R$. rickettsii infected ticks; the only exceptions should be the dominant animals (alpha males and females), as discussed below.

Considering that BSF is unquestionably a current source of great concern to public health, particularly in large urban centers in Brazil (LABRUNA, 2013), Joint Resolution SMA/SES No. 1 , of July 2016, brings important guidelines regarding management of capybara population control for the state of São Paulo. Capybaras evolved as all other animals adapting to their environment. During this

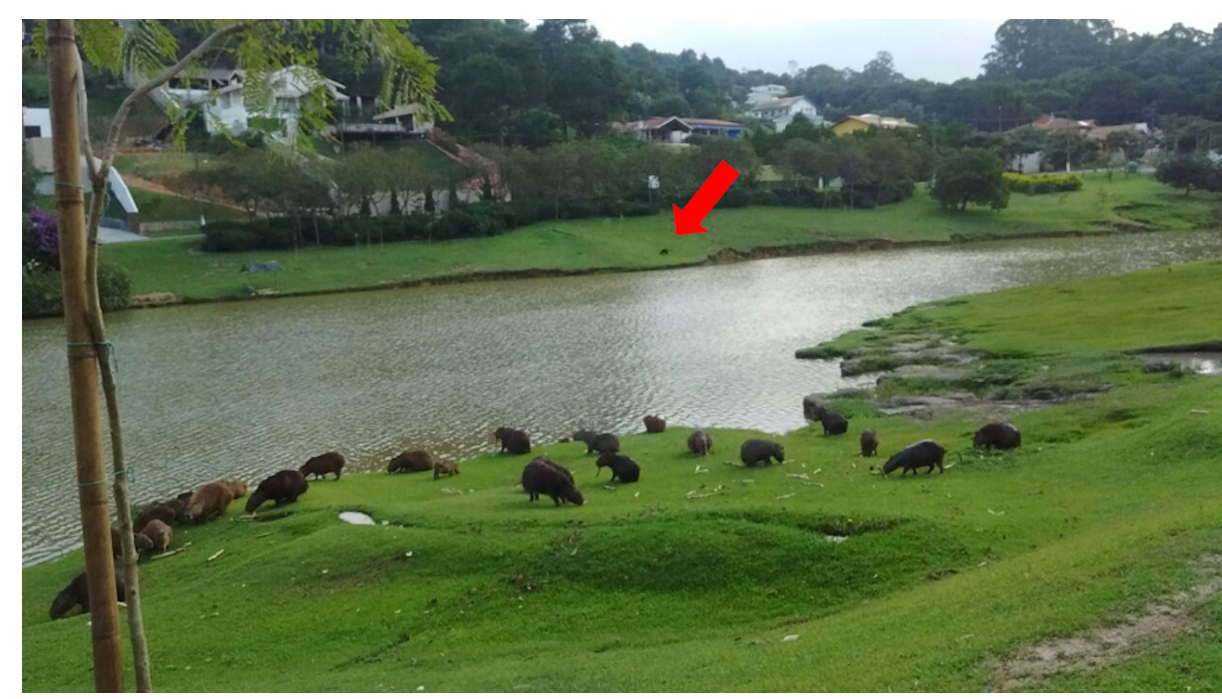

Figure 3 - Alpha male vasectomized isolated from the group - red arrow. 
process, their reproductive behavior was the most important aspect, with rich and unique behaviors especially among males (MOREIRA et al., 2013). Capybara groups always have more females than males, because males are expelled from the group once they reach sexual maturity to form a new group (HERRERA, 2013). However, the sex of these animals is frequently only confirmed when the animal is in containment, with the exception of alpha males, which have very particular characteristics.

According to PAULA and WALKER (2013) male capybaras do not have a defined scrotum, given that their testicles are located in the inguinal region subcutaneously. However, in the present study, it was possible to see from a distance the testicles of alpha males in the scrotum, as also described by ROSENFIELD et al., (2019a)

Still regarding alpha males, we also identified a strong presence of territorial marking behavior in different locations of the environment they inhabited. This finding is in agreement with MACDONALD and HERRERA (2013), who affirmed that the capybara's anal glands, covered with skin and oily secretions, are used as gland marking when rubbed against the vegetation.

Maintaining group cohesion is very important for capybaras. This avoids new groups being created and consequently, triggering an increase in the number of animals in a given region. Thus, all animals contained for surgical procedures were released as soon as they were entirely recovered from anesthetic effects and presented adequate gait and angulation.

Regarding surgical procedures, SILVA et al., (2018) stated that tubal ligations and vasectomies are commonly used for population and birth control among wild animals. Sterilization through both methods of gonad maintenance is very important for capybaras so not to dissociate groups that are kept together due to sexual libido and dominance of some individuals, which are important for the sexual behavior of the group, such as alpha and satellite males and dominant females.

Testosterone is not only important in the maintenance of spermatogenesis and secondary sexual characteristics, but also affects gland markings, libido and social status (HERRERA and MACDONALD, 1994). For these reasons, vasectomy and tubal ligation procedures are highly effective regarding sterilization and maintenance of endocrine, reproductive and behavioral relationships.

Social dominance behavior should be taken into account in studies dealing with the reproductive management of capybaras. Moreover, sterilization procedures must be conducted on dominant individuals of both sexes, even those with seronegative results for BSF, given the relevant role that dominant capybaras have in group cohesion.

Animals were kept under fasting condition for six hours prior to surgical procedures, so to obtain satisfactory anesthetic and postsurgical results. This precaution decreased the risk of bloat.

The capybaras were followed up during the postoperative period for 30 days. None of the animals, with the exception of the aforementioned alpha males, demonstrated any type of behavior or clinical condition that indicated surgical complications that either required intervention or that represented an eminent threat to them. This further confirms that vasectomy and tubal ligation are safe procedures to be conducted on capybaras and that, when properly medicated with long-term analgesic, antibiotic and anti-inflammatory drugs, they are able to recover very well.

Associating management practices for capybaras in areas that are endemic for BSF with quality of life for this species is challenging, since these practices must be effective given the risk imposed to public health. The stochastic model proposed by POLO et al. (2017) and ROSENFIELD et al. (2019b) demonstrated how strategies to control and prevent the transmission of infectious diseases by vectors can be focused on management practices towards amplifying hosts. This showed that actions should be directed towards the capybaras and that important effort has been underway in the planning of reproductive control programs.

POLO et al. (2017) also presented mathematical models showing that the introduction of an $R$. rickettsii-infected capybara carrying at least one infected ticks is able to establish an infection by $R$. rickettsii in a whole population of $A$. sculptum hosted by up to 50 capybaras susceptible to the amplification of the bacteria that causes BSF. This information supports the management actions taken in the present study with surgical procedures and seeking to maintain seronegative dominant individuals within their group of capybaras. This is recommended because they do not represent epidemiological risks and are a minority. Moreover, they are socially important when considering group unity, avoiding dispersion and the formation of subgroups in BSF transmission risk areas.

Joint Resolution SMA/SES No. 1, of July 2016, included reproductive management in transmission risk areas among its guidelines. This represents an interesting alternative for maintaining the well-being of capybaras while hindering the transmission of BSF. 
To the best of our knowledge, this study presents the first description of vasectomy and tubal ligation surgical procedures in capybaras as a reproductive control alternative. This methodology was shown to be very effective in the maintenance of animal quality of life and the social structure of their groups. Other strategies are also being conducted successfully, such as immunocontraceptive vaccines that have been shown to be very effective in males (ROSENFIELD et al., 2019c) and preserved the behavior and hierarchical position of the alpha male.

\section{CONCLUSION}

Tubal ligation, vasectomy and salpingooophorectomy were demonstrated to be simple and low-risk procedures in capybaras. These techniques assist in the population control of this species in areas with risk of BSF transmission, thus decreasing the need for euthanasia.

\section{ACKNOWLEDGEMENTS}

The authors thank the veterinarians: Dr. Rodrigo Hidalgo F. Teixeira PHD, MSc.; to the doctoral student of the Graduate Program of the Department of Preventive Veterinary Medicine and Animal Health of the Faculty of Veterinary Medicine and Animal Science of the University of São Paulo (FMVZ / USP) Hector Ribeiro Benatti; Dr. Celso Eduardo de Souza, veterinarian of the Endemic Superintendence (SUCEN / SP) and Francisco Uchoa veterinarian of the Endemic Superintendence (SUCEN / $\mathrm{SP}$ ); the wildlife management team of the Department of Fauna of the São Paulo State Department of the Environment (DEFAU / SMA), to field assistants Jairo Sandi and Severino da Silva, with the help of these professionals, made it possible job. This study was partially funded by management enterprises and company AZ Nunes e Cia Ltda.

\section{BIOETHICS \\ AND \\ BIOSSECURITY COMMITTEE APPROVAL}

The present study was approved by the Ethic Committee on Animal Use of the School of Veterinary Medicine and Husbandry of São Paulo University (CEUA/FMVZ/USP) under protocol no 1106020919 .

\section{DECLARATION OF CONFLICT OF INTERESTS}

The authors declare no conflict of interest. The founding sponsors had no role in the design of the study; in the collection, analyses, or interpretation of data; in the writing of the manuscript, and in the decision to publish the results.

\section{AUTHORS' CONTRIBUTIONS}

FBPN, MBL and CSP conceived, designed and directed the study. All authors performed the experiments. FBPN,
MBL and CSP analyzed and interpreted the data. FBPN and CSP wrote the manuscript. All authors critically revised the manuscript and approved of the final version.

\section{REFERENCES}

BARROS, B. J. et al. The efficiency of nylon 6.6 (polyamide) cable ties as a method for massive ligatures of ovarian pedicles and uterine stubs in ovariohysterectomy of bitches (Canis familiaris). Arquivos de Ciências Veterinárias e Zoologia, v.12, n.1, p.4760, 2009. Available from: <http://https://doi.org/10.25110/arqvet. v12i1.2009.2934>. Accessed: Jan. 22, 2020. doi: 10.25110/arqvet. v12i1.2009.2934.

BOVO, A. A. A. et al. Capybaras (Hydrochoerus hydrochaeris) in anthropogenic environments: challenges and conflicts. In: COSTA, C.G.; LYRA-JORGE, M.C.; VERDADE, L.M. Biodiversity in agricultural landscapes of southeastern Brazil, De Gruyter Open, Berlin, 2016. Cap.11, p.178-186.

HERRERA, E. A. Capybara social behavior and use of space: patterns and processes. In: MOREIRA, J.R.; FERRAZ, K.M.P.M.B.; HERRERA, E.A.; MACDONALD, D.W. Capybara biology, use and conservation of an exceptional neotropical species, Ed. Springer, London, 2013. Cap.11, p.195-207.

HERRERA, E. A.; MACDONALD, D. W. 1994. Social significance of scent marking in capybaras. Journal of Mammalogy, v.75, n.2, p.410-415, 1994. Available from: <https://academic.oup.com/ jmammal/article-abstract/75/2/410/836346?redirectedFrom=fullte xt>. Accessed: Jan. 22, 2020. doi: 10.2307/1382561.

LABRUNA, M. B. Brazilian spotted fever: the role of capybaras. In. MOREIRA, J. R.; FERRAZ, K. M. P. M. B.; HERRERA, E. A.; MACDONALD, D. W. Capybara biology, use and conservation of an exceptional neotropical species, Ed. Springer, London, 2013. Cap. 23 p. $371-384$

MACDONALD, D. W. et al. Behavioural, anatomical and chemical aspects of scent marking amongst Capybaras (Hydrochoerus hydrochaeris) (Rodentia: Caviomorpha). Journal of Zoology. London. v.202, p.341-360, 1984. Available from: <https://doi. org/10.1111/j.1469-7998.1984.tb05087.x>. Accessed: Jan. 22, 2020. doi: 10.1111/j.1469-7998.1984.tb05087.x.

MACDONALD, D. W.; HERRERA, E. A. Capybara scent glands and scent-marking behavior. In: MOREIRA, J. R.; FERRAZ, K. M. P. M. B.; HERRERA, E. A.; MACDONALD D. W. Capybara biology, use and conservation of an exceptional neotropical species, Ed. Springer, London, 2013, Cap.10, p.185-193.

MOREIRA, J. R. et al. Capybara demographic traits. In. MOREIRA, J.R.; FERRAZ, K.M.P.M.B.; HERRERA, E.A.; MACDONALD, D.W. Capybara biology, use and conservation of an exceptional neotropical species, Ed. Springer, London, 2013, Cap.8, p.147- 167.

PAULA, T. A. R.; WALKER, N. J. Reproductive morphology and physiology of the male capybaras. In: MOREIRA, J. R.; FERRAZ, K. M. P. M. B.; HERRERA, E. A.; MACDONALD, D. W. Capybara biology, use and conservation of an exceptional neotropical species, Ed. Springer, London, 2013, Cap.6, p.107-129.

PASSOS NUNES, F. B. et al. 2019. The dynamics of ticks and capybaras in a residential park area in southeastern Brazil: 
implications for the risk of Rickettsia rickettsii infection. VectorBorne and Zoonotic Diseases. v.19, n.10, p.711-716. Available from: <http://doi.10.1089/vbz.2019.2479>. Accessed: Jan. 22, 2020. doi: 10.1089/vbz.2019.2479.

POLO, G. et al. Transmission dynamics and control of Rickettsia rickettsii in populations of Hydrochoerus hydrochaeris and Amblyomma sculptum. PLoS Neglected Tropical Diseases, v.11, n.6: e0005613, 2017. Available from: <https://doi.org/10.1371/ journal.pntd.0005613>. Accessed: Jan. 22, 2020. doi: 10.1371/ journal.pntd.0005613.

RAMÍREZ-HERNÁNDEZ, A. et al. Clinical and serological evaluation of capybaras (Hydrochoerus hydrochaeris) successively exposed to an Amblyomma sculptum-derived strain of Rickettsia rickettsi. Scientific Reports (in press). Available from: $<$ https://doi. org/10.1038/s41598-020-57607-5>. Accessed: Jan. 22, 2020. doi: $10.1038 / \mathrm{s} 41598-020-57607-5$.

ROSENFIELD, D. A.; PIZZUTTO, C. S. On the importance of alpha behavior integrity in male capybara Hydrochoerus hydrochaeris (Mammalia: Rodentia: Caviidae) following immunocontraceptive treatment. Journal of Threatened Taxa, v.11, n.8, p.13967-13976, 2019a. Available from: <http://doi.org/10.11609/ jott.4747.11.8.13967-13976>. Accessed: Jan. 22, 2020. doi: 10.11609/jott.4747.11.8.13967-13976.
ROSENFIELD, D. A. et al. Brazilian spotted fever prevention through a non-lethal capybara population control strategy. Revista da Sociedade Brasileira de Medicina Tropical, v.52:e20190156: 2019b. Available from: <http://dx.doi.org/10.1590/0037-8682-01562019>. Accessed: Jan. 22, 2020. doi: 10.1590/0037-8682-0156-2019.

ROSENFIELD, D. A. et al. Field-testing a single-dose immunocontraceptive in free-ranging male capybara (Hydrochoerus hydrochaeris): Evaluation of effects on reproductive physiology, secondary sexual characteristics, and agonistic behavior. Animal Reproduction Science, v.209, p.106148, 2019c. Available from: $<$ https://doi.org/10.1016/j.anireprosci.2019.106148>. Accessed: Jan. 22, 2020. doi: 10.1016/j.anireprosci.2019.106148.

SILVA, D. F. et al. Population control of invasive wild species through tubal ligation and vasectomy in primates Callithrix penicillata: Case report. Veterinária e Zootecnia, v.25, n.1, p.99105, 2018. Available from: <https://doi.org/10.35172/rvz.2018. v25.7>. Accessed: Jan. 22, 2020. doi: 10.35172/rvz.2018.v25.7.

SOUZA, C. E. et al. Experimental infection of capybaras Hydrochoerus hydrochaeris by Rickettsia rickettsii and evaluation of the transmission of the infection to ticks Amblyomma cajennense. Veterinary Parasitology, v.161, n.1-2, p.116-121, 2009. Available from: <https://doi: 10.1016/j.vetpar.2008.12.010>. Accessed: Jan. 22, 2020. doi: 10.1016/j.vetpar.2008.12.010. 